\title{
Therapeutic self-management - development of a flowchart to support decision-making: qualitative study
}

Gestão do regime terapêutico - construção de fluxograma de apoio à tomada de decisão: estudo qualitativo

Gestión del régimen terapéutico - construcción del diagrama de flujo para apoyar la toma de decisiones: estudio cualitativo

Liliana Andreia Neves da Mota*; Maria Adelaide Sousa Cruz ${ }^{* *}$; Catarina Alexandra Oliveira Costa***

\section{Abstract}

Background: Liver transplantation is a therapeutic modality in situations of advanced liver disease whose success depends on how patients deal with a new and complex therapeutic regimen in their daily lives.

Objectives: To develop a flowchart to support nursing decision-making on the therapeutic self-management of liver transplant patients.

Methodology: Qualitative longitudinal study conducted between January and December 2013 in a transplantation center, using retrospective content analysis of nursing records and consensus meetings with nurses.

Results: The flowchart included the following areas: medication regimen, dietary regimen, lifestyles, and complications. Nurses reached a 90\% consensus on the specifications of each intervention included in these areas, with the purpose of achieving continuity of care.

Conclusion: The systematization of information in a flowchart allows for a better identification of each patient's needs with a view to preparing discharge, the continuity and quality of care.

Keywords: self-care; liver transplantation; nursing

\section{Resumo}

Enquadramento: O transplante hepático é uma modalidade terapêutica em situações de doença hepática avançada e cujo sucesso depende do modo como o doente incorpora no seu quotidiano um novo regime terapêutico complexo.

Objetivos: Desenvolver um fluxograma de apoio à decisão clínica de enfermagem no âmbito da gestão do regime terapêutico da pessoa submetida a transplante hepático.

Metodologia: Estudo qualitativo, longitudinal, realizado num centro de transplantação, com recurso à análise de conteúdo retrospetiva aos registos de enfermagem e reuniões de consenso com os enfermeiros. Realizou-se de janeiro a dezembro de 2013. Resultados: O fluxograma agrega as áreas do regime medicamentoso, regime dietético, hábitos de vida e as complicações. As especificações das intervenções agregadas nas áreas referidas reuniram consenso em mais de 90\% dos enfermeiros, tendo em vista a continuidade dos cuidados.

Conclusão: A sistematização da informação num fluxograma permite o melhor reconhecimento das necessidades dos doentes tendo em vista a preparação do regresso a casa, a continuidade e qualidade dos cuidados.

Palavras-chave: autocuidado; transplante de fígado; enfermagem

\footnotetext{
* MSc., Ph.D. student, Nursing Sciences, University of Porto, Institute of Biomedical Sciences Abel Salazar. Adjunct Professor, in Portuguese Red Cross Nursing School, Oliveira de Azeméis, 3720-126, Oliveira de Azeméis, Portugal [saxoenfermeira@gmail.com]. Contribution to the article: data collection and analysis, discussion of results, and article writing. Address for correspondence: Travessa do Formal 42, 4415-653, Lever Vila Nova de Gaia, Portugal

* RN, Nurse specialist in rehabilitation nursing, Liver and Pancreas Transplantation Unita, Centro Hospitala do Porto - Hospital Santo António, 4099-001, Porto, Portugal [masc29@gmail.com]. Contribution to the article: data collection and discussion.

**** MSc., Nurse specialist in medical-surgical nursing, Porto Hospital Center - Hospital Santo António, 4099001, Porto, Portugal [catarinaoliveira1979@gmail.com]. Contribution to the article: data collection and
} discussion.

\section{Resumen}

Marco contextual: El trasplante de hígado es una modalidad terapéutica que se aplica en situaciones de enfermedad hepática avanzada, y cuyo éxito depende de cómo el paciente incorpore en su vida diaria un nuevo régimen de tratamiento complejo.

Objetivos: Desarrollar un diagrama de flujo de apoyo a la decisión clínica de enfermería en la gestión del régimen terapéutico de la persona sometida a trasplante de hígado.

Metodología: Estudio cualitativo, longitudinal, realizado en un centro de trasplante mediante el análisis de contenido retrospectivo de los registros de enfermería y las reuniones de consenso con los enfermeros. Se realizó entre enero y diciembre de 2013.

Resultados: El diagrama de flujo incluye las áreas de régimen de medicación, régimen alimenticio, estilo de vida y complicaciones. Las especificaciones de las intervenciones en las áreas mencionadas obtuvieron un consenso en más del $90 \%$ de los enfermeros, teniendo en cuenta la continuidad de los cuidados.

Conclusión: La sistematización de la información en un diagrama de flujo permite reconocer mejor las necesidades de los pacientes con el fin de preparar el regreso a casa, la continuidad y la calidad de la atención.

Palabras clave: autocuidado; trasplante de hígado; enfermería

Received for publication: 27.07 .16

Accepted for publication: 28.11.16 


\section{Introduction}

Liver transplantation is the last-line treatment option for advanced liver disease, with significant impact on these patients' quality of life. Therefore, the adoption of behaviors that ensure transplant viability and promote liver recipient's quality of life is essential.

After liver transplantation, people are challenged to rethink their attitudes towards health/disease to guarantee the success of the transplantation. According to the International Council of Nurses, this is associated with the concept of self-care aimed at "taking care of what is needed to maintain oneself, keep oneself going and handle basic individual and intimate necessities and activities in daily life" (Conselho Internacional de Enfermeiros, 2015, p. 9). One of the issues addressed in the literature on liver transplantation is the concept of therapeutic self-management.

Therapeutic regimen management as a self-initiated action aims to promote well-being, based on a conscious choice and depending on the person's will (Conselho Internacional de Enfermeiros, 2011).

Nursing care that depends on the nurse's decisionmaking can and should play a key role in improving the adaptability, action, transformation, and optimization of all conditions and circumstances that surround and influence patients' behaviors, in order for them to develop their self-care skills (Mota, 2011). Information systems can then be seen as an opportunity to rethink and redefine current work processes in order to take advantage of new possibilities for information management to reduce costs, increase productivity, and improve service levels (Mota, 2010; Pereira, 2007). Information systems should be "able to assert themselves as solid structures capable of ensuring efficient processes for the collection, processing, organization, and management of data resulting from care processes" (Mota, Pereira, \& Sousa, 2014, p. 86). Thus, this study aimed to develop a flowchart to support nursing clinical decision-making on the therapeutic regimen management of liver transplant patients, with a view to promoting care continuity.

In this study, data collected by nurses focused on their decision-making process will be used to develop a flowchart to guide clinical decision-making, with a view to integrating it into the information system in use.

\section{Background}

The concept of therapeutic regimen management is very similar to that of disease Therapeutic self-management. The issue of chronically ill people relates to the adoption of health/disease selfmanagement behaviors, with a view to achieving balanced family, professional, and social relationships (Fry \& Bates, 2012; Redman, 2004).

In their return home, liver transplant patients are challenged to integrate "into daily living a program for treatment of illness and its sequelae" (NANDA International, 2003, pp. 188-193), pointing us to the concept of therapeutic regimen management. The latest version of the International Classification for Nursing Practice (Conselho Internacional de Enfermeiros, 2015), does not describe the term therapeutic self-management related to the use of terms such as: self-care, regime, medication regime, dietary regime, exercise regime, ability to manage, attitude to regime, etc.

The current information system uses the beta version of the International Classification for Nursing Practice (ICNP) in which the definition of therapeutic self-management is considered an adherence behavior that consists of "integrating into daily living a program for treatment of illness and its sequelae that is satisfactory for meeting specific health goals" (Conselho Internacional de Enfermeiros, 2011, p. 62). Other terms are used in the literature to describe the concept of therapeutic self-management, such as only self-management, associated with self-care, which Lorig and Holman (2003) describe as the learning and training of skills necessary to ensure an active and emotionally satisfactory life in situations of chronic illness. These authors established five core self-management skills: problem solving, decisionmaking, resource utilization, forming of a patient/ health care provider partnership and taking action.

Other concepts, such as adherence, are also associated with therapeutic self-management. According to the International Classification for Nursing Practice, adherence is defined as:

Self-initiated action to promote wellness, recovery and rehabilitation, following directions without deviation, devoted to a set of actions or behaviors. Compliant with treatment regimen, taking medicine as instructed, behavior change 
for the better, signs of healing, collection of medicine on due date, internalization of the value of health care behavior and obeying instructions regarding treatment. (Conselho Internacional de Enfermeiros, 2015, p. 2)

Some authors suggest the need for clarifying concepts:

Therapeutic self-management is a more comprehensive concept that encompasses adherence, but goes beyond volition and includes, among other things, the ability to decide on a behavior adjustment in case of a change in a symptom or a new circumstance, incorporating, for this reason, self-knowledge and the technical knowledge required to interpret and act accordingly. (Bastos, 2013, p. 66)

Medication regimen non-adherence rates in liver transplantation are around 25.28\%, which includes taking non-prescribed medication, not completing the course of medication, deviating from the prescribed dose and frequency (Telles-Correia, Barbosa, Mega, Barroso, \& Monteiro, 2007). In a study on the therapeutic adherence of liver and kidney transplant patients, Moreno (2012) found that $44 \%$ of patients reported non-adherence behaviors. The rates of non-adherence to the medication regimen after liver transplantation have a strong impact on morbidity and mortality, decrease the quality of life, and increase health care costs (Telles-Correia, Barbosa, Mega, Barroso, \& Monteiro, 2008).

In order to reduce the impact of non-adherence rates, nurses should help patients to acquire knowledge and skills to manage their therapeutic regimen. "The careful and appropriate transmission of information between patients and health care professionals at discharge, as well as its understanding and assimilation are very important for the continuity of quality care at home" (Morais, 2010, p. 34).

With regard to the issue of care continuity, it is important to reflect about how nurses collect, process, and document patient data within the same health care setting, with a view to ensuring continuity within the same professional group.

"During the preparation for returning home, the nurse should be able to identify the patient's needs and available resources, so as to plan interventions that can help him/her." (Morais, 2010, p. 38).

With the technological advances in information systems, systems capable of supporting clinical decision-making are increasingly necessary.
The design of the data model on nursing decision-making should encompass four major components: initial assessment data, data on nursing diagnoses, data on diagnoses status (i.e., expected goals/outcomes), nursing interventions, and the systematic assessment of client outcomes/ evolution. (Ordem dos Enfermeiros, 2007, p. 2)

Thus, studies with an impact on nurses' clinical practice, taking their needs as reference, should be conducted for the continuous improvement of care quality and continuity of care.

\section{Research Questions}

As a result of our concerns in clinical practice, we have formulated the following research questions:

What do nurses consider relevant in their clinical decision-making on therapeutic self-management?

How should data perceived as relevant by nurses be systematized?

How is continuity of care ensured?

\section{Methodology}

The study was conducted in the Liver and Pancreas Transplantation Unit (Unidade de Transplantação Hepática e Pancreática - UTHP) of the Hospital Center of Porto (Centro Hospitalar do Porto - CHP).

The UTHP uses electronic nursing records through the Support System for Nursing Practice (Sistema de Apoio à Prática de Enfermagem - SAPE), using the beta version of a classification (ICNP).

A qualitative and longitudinal study, based on interpretative research, was conducted in two phases. Qualitative studies are of extreme importance given the high relevance of participants' point of view (Flick, 2005).

In phase I, a retrospective content analysis was performed to nursing records, in order to identify the information included in the nursing diagnosis process, as well as the interventions identified by nurses as having referential integrity for therapeutic self-management. Sixty nursing records were analyzed, corresponding to the number of patients who underwent a liver transplant between January and December 2013 (data collection period). A thematic analysis was performed to the data 
(Bardin, 2008). The categories had been previously established using the categories defined by Mota (2011) regarding the therapeutic self-management in a similar context: Ability to manage the dietary regimen; Ability to manage the medication regimen; and Willingness and ability to detect complications.

In phase II, the nurses working at the UTHP (15 nurses) met in four consensus meetings with the purpose of gaining a better understanding of the therapies that best described their intervention concerning therapeutic self-management, as well as defining the criteria for assessing the patient's knowledge and skills, thus promoting continuity of care. Each meeting lasted 60 minutes and was held at the nursing office of the UTHP. The group meetings allow addressing common problems: a specific problem is put forward, and the group has to discuss alternatives to solve the problem, going beyond personal opinions (Flick, 2005). We considered the criteria that gained a $75 \%$ consensus among nurses.

The participation in the study was voluntary. The participants' anonymity was ensured, as well as their possibility to withdraw from the study case, which did not occur. The study was approved by the CHP Executive Board.

\section{Results}

When examining nursing records regarding therapeutic self-management, we found that nurses only identified the nursing diagnosis of opportunity for therapeutic self-management. After the identification of this nursing diagnosis, nurses implemented informational interventions aimed at "telling somebody about something" (Conselho Internacional de Enfermeiros, 2015, p. 60), particularly with the purpose of teaching by "Giving systematic information to somebody about health related subjects" (Conselho Internacional de Enfermeiros, 2015, p. 40). Nursing interventions were distributed by areas such as medication regimen, dietary regimen, lifestyles, and complications.

Table 1 shows the aggregation of the interventions found in the information system in use, based on the categories defined by Mota (2011). It should be noted that a new category emerged from data analysis: Ability to manage lifestyles.

Table 1

Aggregation of the interventions found in the system in use and corresponding specification

\begin{tabular}{|c|c|c|}
\hline Categories & Interventions in the system & Specification \\
\hline \multirow{4}{*}{$\begin{array}{l}\text { Ability to manage medication } \\
\text { regimen }\end{array}$} & $\begin{array}{l}\text { To provide reading material about the } \\
\text { therapeutic regimen }\end{array}$ & \\
\hline & To teach about medication regimen & $\begin{array}{l}\text { - Drug name } \\
\text { - Drug action } \\
\text { - Drug scheduling } \\
\text { - Dosage form }\end{array}$ \\
\hline & $\begin{array}{l}\text { To teach about medication self-admin- } \\
\text { istration }\end{array}$ & - Strategies for remembering to take medication \\
\hline & $\begin{array}{l}\text { To teach about the response/reaction to } \\
\text { medication }\end{array}$ & $\begin{array}{l}\text { - Adverse effects } \\
\text { - Forgetting to take medication } \\
\text { - Importance of taking medication correctly }\end{array}$ \\
\hline $\begin{array}{l}\text { Ability to manage dietary } \\
\text { regimen }\end{array}$ & To teach about eating habits & $\begin{array}{l}\text { - Purpose of a meal plan } \\
\text { - To teach about allowed and non-allowed foods } \\
\text { - Importance of oral hydration }\end{array}$ \\
\hline & To teach about exercise habits & $\begin{array}{l}\text { - Importance of physical exercise } \\
\text { - To provide guidance on adequate activities }\end{array}$ \\
\hline Ability to manage lifestyles & $\begin{array}{l}\text { To promote the adaptation to new } \\
\text { lifestyles }\end{array}$ & $\begin{aligned} \text { - To provide guidance on healthy lifestyles: } \\
\text { - Stop smoking } \\
\text { - Dental care } \\
\text { - Skin care } \\
\text { - Use of condom } \\
\text { - Caution with animals and plans } \\
\text { - Return to work and driving } \\
\end{aligned}$ \\
\hline
\end{tabular}




\begin{tabular}{|c|c|c|}
\hline \multirow{3}{*}{$\begin{array}{l}\text { Ability to detect/prevent } \\
\text { complications }\end{array}$} & $\begin{array}{l}\text { To teach about complications of an } \\
\text { ineffective therapeutic regimen man- } \\
\text { agement }\end{array}$ & $\begin{array}{l}\text { - Medication effects } \\
\text { - Complications }\end{array}$ \\
\hline & To teach about signs of infection & - To provide guidance on how to avoid infections \\
\hline & To teach about self-monitoring & $\begin{array}{l}\text { - Self-monitoring } \\
\text { - To describe signs and symptoms of complications } \\
\text { - Association between self-monitoring and complica- } \\
\text { tions }\end{array}$ \\
\hline
\end{tabular}

Based on these results and using the consensus technique, the nurses defined the criteria that should be met in each intervention, so that the whole team recognizes each patient's level of acquisition of knowledge and skills related to therapeutic self-management. Thus, the entire team actually knows what has already been implemented and what still needs to be implemented.

The specification column in Table 1 shows the criteria that the nurses considered relevant to be applied to each intervention.

\section{Ability to manage medication regimen}

"When I'm talking with the patient about the medication regimen I tell him ... of course ... about the drug name and schedule" (I1, December, 2013); "the dose is also important, although it can vary" (I4, December, 2013); "some patients tell me . . . I don't know the name . . . but if I see it I'll know" (I10, December, 2013); "I think that patients need to know why they're taking their medication" (I15, December, 2013).

Based on the nurses' accounts, we believe that the intervention specifications to teach about the medication regimen consisted in providing the name, scheduling, dose and action of the drug. The drug dose was not considered in the specifications because it did not have the consensus of more than $75 \%$ of the nurses, as they believed that, since the dose varied, there was no need to teach about it.

Several nurses emphasized to patients the importance of taking their medication at the right time, encouraging them to use an alarm clock: "so that they never forget to take their medication, I even tell them to set an alarm on their mobile phones" (I4, December, 2013); "I encourage many of them to use the alarm clock in their mobile phones to remind them to take the medication . . . because some of them like to sleep until late and they would end up missing the time for taking their medication" (I2, December, 2013).
Therefore, based on these accounts, we included strategies for remembering to take medication in the specification of the intervention to teach about medication self-administration. Moreover, there were also issues related to medication effects: "I take the time to explain to them that the medication may have some negative effects" (I6, December, 2013); "I think it's important that the patient is aware of the need of always taking the medication at the right time ... but we all know that, in some cases, this does not happen and that's why I tell them what they should do" (I9, December, 2013); "I'm more uncomfortable talking about this topic. ... I must confess ... telling them that they may develop other diseases by taking their medication. . . It is not always easy . . . but we have to tell them ... . I even try to demystify the side effects ... I believe that some of them would even stop taking it" (I2, December, 2013).

Thus, the following specifications were associated with the intervention to teach about the response/ reaction to medication: adverse effects, forgetting to take medication, and importance of taking medication correctly.

\section{Ability to manage dietary regimen}

"One of our patients' major concern is without a doubt what they can or cannot eat ... and it's also a concern of ours ... because some of them go through a dramatic weight gain after the transplantation" (I5, December, 2013); "it's the same for everyone, when they start eating they immediately want to know what they can eat, and then I take the opportunity to talk about the importance of drinking water and the restrictions" (I6, December, 2013); "it's definitely the most interesting topic for families and patients ... I think it's very important to include the family here" (I11, December, 2013).

In this way, the following specifications emerged from the intervention to teach about eating habits: the purpose of a meal plan, to teach about allowed 
and non-allowed foods, and the importance of oral hydration.

\section{Ability to manage lifestyles}

Based on our analysis, the topic of promotion of healthy lifestyles is a constant concern for the team: "we all agree that they should change their lifestyles ... stop smoking ... even before the transplant, but few do so ... so we have to do it later" (I8, December, 2013); "I talk with them about the need to go for a walk ... I tell those who smoke to use the time that they're hospitalized to stop smoking. . . and to not resume smoking" (I10, December, 2013).

Therefore, the following specifications were associated with the intervention to teach about exercise habits: importance of physical exercise, and to provide guidance on adequate activities. In the intervention to promote the adaptation to new lifestyles, the following specifications emerged: provide guidance on healthy lifestyles (stop smoking, dental care, skin care, use of condom, caution with animals and plans, return to work and driving).

\section{Ability to detect/prevent complications}

All nurses talked with the patients about signs of rejection, prevention of infections, and complications of an inefficient self-management: "I emphasize the importance of hand washing" (I1, December, 2013); "when I give them their medication, I talk to them about more than the effects, about what happens if they don't take it properly" (I8, December, 2013); "patients should be well aware of the warning signs" (I9, December, 2013).

Thus, the following specifications emerged for each of the three interventions: to teach about complications of an ineffective therapeutic regimen management: medication effects and complications; to teach about signs of infection: to provide guidance on how to avoid infections; and to teach about self-monitoring: self-monitoring, to describe signs and symptoms of complications, and association between self-monitoring and complications.

With the purpose of ensuring continuity of care and the prioritization of interventions throughout the health care process, all nurses only considered the whole process of intervention systematization when the patient described all the items in the specification. However, they only considered the validation of three of the four specifications in the intervention to teach about medication regimen, with drug scheduling being a core item.

In order to make the decision-making process more accessible and clinically useful, this process was systematized in a flowchart (see Figure 1). Nurses reached a $90 \%$ consensus in all the resulting items of the flowchart.

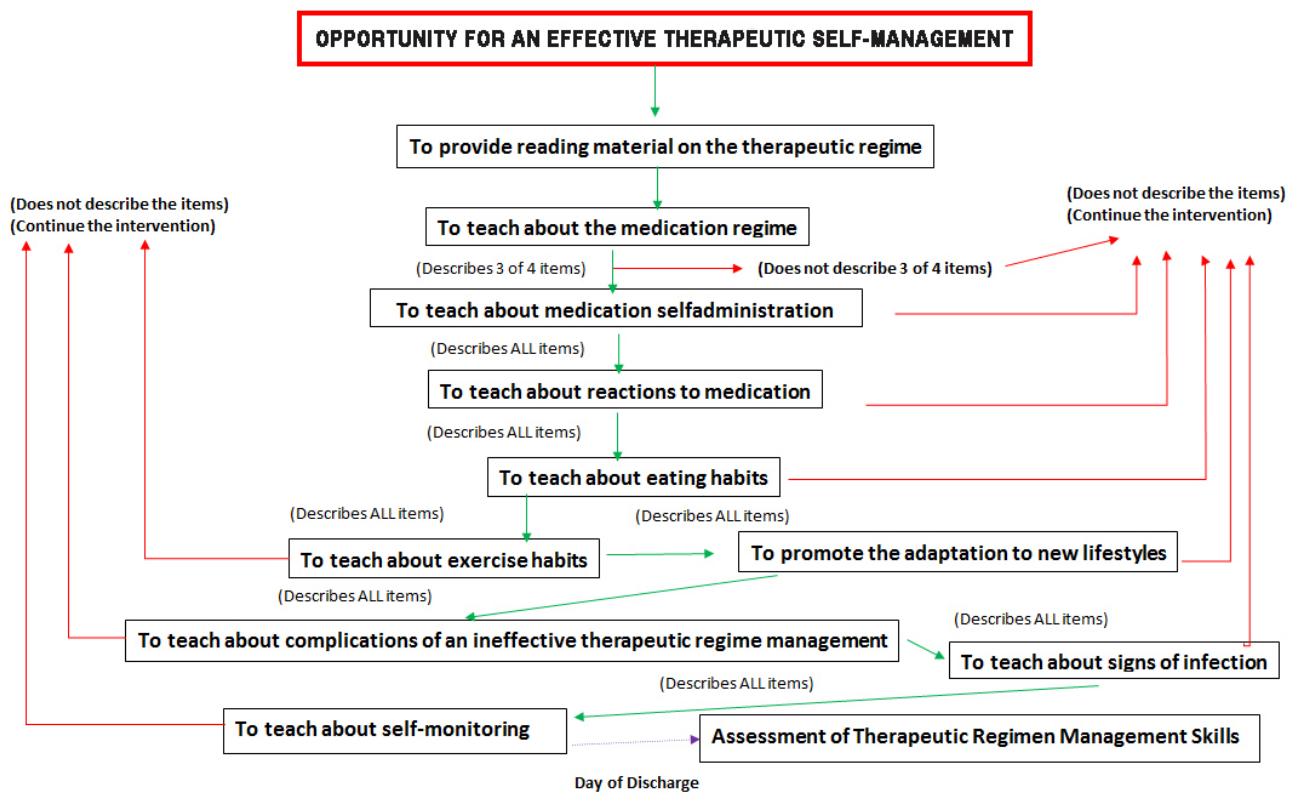

Figure 1. Flowchart for therapeutic self-management. 
This flowchart systematizes nursing therapeutic interventions with a view to preparing the return to home, and the continuity and quality of care.

\section{Discussion}

The areas described by nurses as essential for the therapeutic self-management are well recognized by the scientific community: medication regimen, dietary regimen, lifestyles, and complications (Moreno, 2012; Mota, 2011). These areas reflect the nurses' intervention plan with referential integrity for the single nursing diagnosis identified in therapeutic self-management: opportunity for an effective therapeutic self-management. The classification of this nursing phenomenon in the field of probabilities (opportunity to) demonstrates the nurses' desire for a successful achievement of the phenomenon, judging it as effectiveness, which relates to the success of the therapeutic self-management and its impact on transplantation outcomes.

The consensus reached in the definition of the specifications for each intervention with referential integrity for therapeutic self-management indicates that all nurses working at that care setting addressed the issues described in the specifications while implementing the interventions. The issue lies in the systematization of information in order to promote the continuity of care.

A critical analysis of the flowchart shows that there is some form of prioritization in the order in which the different teachings on therapeutic self-management are systematized. The domain related to the medication regimen is the first one, because it is the one that patients and professionals valued the most, followed by the eating habits, exercise, and lifestyles. Liver transplant patients should incorporate into their daily living a complex dietary and medication regimen, as well as develop self-monitoring behaviors (Acurcio et al., 2009). According to Moreno (2012, p. 7), "diet (28.8\%), physical exercise (33.3\%), and smoking cessation $(10.7 \%)$ are the health professionals' indications that patients reported having more difficulty in complying with", i.e. despite the hierarchy of interventions and the recognition of the patient's difficulties in complying with recommendations, nurses must maintain the intentionality and intensity of their actions throughout the process. As a result, the process of monitoring outcomes emerges as essential for understanding the skills acquired by patients.

The nurses' ability to identify the patient's needs, difficulties and potential for autonomy allows for the elaboration of a more care-adjusted plan, which will increase the patient's satisfaction and well-being. Patients assimilate the information at their own pace, which further emphasizes nurses' assessment skills, in favor of the continuity of care. In fact, liver transplant patients' potential for autonomy should be developed to enable them to manage their therapeutic regimen with the purpose of enhancing the quality of care and continuously improving their quality of life. According to Forsberg, Backman, and Svensson (2002), nursing care is a resource mobilizer, enabler and facilitator of health and self-care promotion activities.

The flowchart allows developing a clinical script to guide nursing practice for the information system in use. In turn, this script facilitates the analysis of the patient's skills and competences that are acquired at any moment of the care process, enabling care providers to plan the next intervention, without the need for a standardized care that do not meet the patients' actual needs.

Clinical practice is guided by the patients' needs in order to provide them with quality of life and to ensure a successful transplantation. Therefore, carerelated goals are achievable, leading to a greater visibility of nursing sensitive outcomes.

A limitation of this study was the small number of participants (15); hence, it would be relevant to replicate it in another transplantation center and conduct a comparative study. This type of studies would contribute to reducing fragmentation and, therefore, to the standardization of clinical care scripts for liver transplant patients.

\section{Conclusion}

The development of clinical scripts to guide clinical practice promotes the continuity and quality of the care delivered by different professionals with common goals. The core areas of therapeutic self-management in liver transplantation are the medication therapeutic self-management, the dietary regimen, lifestyles, and complications. Each of these areas includes 
interventions that are standardized in the information system in use. Nurses indicated specifications that should be taken into account when implementing each intervention, with the purpose of achieving continuity and quality of care.

Information becomes more complex over time, depending on the patient's ability and willingness. In any case, the intensity of the monitoring should be carefully assessed and remain constant over time.

The flowchart allows systematizing the nursing therapeutic interventions included in the information system in use in order to ensure the continuity and quality of care. Nurses turn their attention to the development of skills related to therapeutic self-management in transplant recipients, being able to easily recognize the acquired skills. As a result, they can focus on the promotion of skills that have not been acquired with a view to empowering the patient and, in this way, achieving a successful transplantation. Future studies should produce indicators of process and outcome, so as to highlight health gains sensitive to nursing care.

\section{References}

Acurcio, F. A., Silva, A., Ribeiro, A., Rocha, N., Silveira, M., Klein, C., \& Rozenfeld, S. (2009). Complexidade do regime terapêutico prescrito para idosos. Revista Associação Médica Brasileira, 55(4), 468-474. doi: 10.1590/S0104-42302009000400025

Bardin, L. (2008). Análise de conteúdo. Lisboa, Portugal: Edições 70 .

Bastos, F. (2013). A pessoa com doença crónica: Uma teoria explicativa sobre a problemática da gestão e do regime terapêutico (Ph.D. Thesis). Retrieved from http:/hdl. handle.net/10400.14/11990

Flick, U. (2005). Métodos qualitativos na investigação científica. Lisboa, Portugal: Monitor.

Forsberg, A., Backman, L., \& Svensson, E. (2002). Liver transplant recipients 'ability to cope during the first 12 months after transplantation: A prospective study. Scandinavian Journal of Caring Sciences, 16(4), 345-352 doi: 10.1046/j.14716712.2002.00100.x

Conselho Internacional de Enfermeiros. (2011). CIPE versão 2: Classificação internacional para a prática de enfermagem. Lisboa, Portugal: Lusodidacta.

Conselho Internacional de Enfermeiros. (2015). CIPE: Classificação internacional para a prática de enfermagem. Lisboa, Portugal: Lusodidacta.
Fry, N., \& Bates, B. G. (2012). The tasks of self-managing hepatitis C: The significance of disclosure. Psichology \& Health, 27(4), 460-474. doi: 10.1080/08870446.2011.592982

Lorig, K. R., \& Holman, H. R. (2003). Self-management education: History, definition, outcomes and mechanisms. Annals of Behavioral Medicine, 26(1), 1-7. doi: 10.1207/ S15324796ABM2601_01

Morais, J. P. (2010). Preparação do regresso a casa: Do hospital ao contexto familiar (Masters dissertation). Retrieved from http:/hdl.handle.net/10400.14/9210

Moreno, M. F. (2012).Adesão àterapêutica em doentessubmetidos a transplante bepático e renal (Masters dissertation). Retrieved from http://hdl.handle.net/10362/9707

Mota, L. A. (2010). Sistemas de informação de enfermagem: Um estudo sobre a relevância da Informação para os médicos (Masters dissertation). Retrieved from http:/hdl.handle. net/10216/55361

Mota, L. (2011). O perfil de autocuidado dos clientes: Exploração da sua influênca no sucesso após transplante bepático (Masters dissertation). Retrieved from http:/hdl.handle. net/10400.26/9234

Mota, L., Pereira, F., \& Sousa, P. (2014). Sistemas de informação de enfermagem: Exploração da informação partilhada com os médicos. Revista de Enfermagem Referência, 4(1), 85-91. doi: 10.12707/RIII12152

NANDA International. (2003). Nursing diagnoses: Definitions $\mathcal{E}$ classification. Philadelphia, PA: Author.

Ordem dos Enfermeiros. (2007). Sistema de informação em enfermagem: Princípios básicos da arquitetura e principais requisitos técnico-funcionais. Lisboa, Portugal: Autor.

Pereira, F. M. (2007). Informação e qualidade do exercício profissional dos enfermeiros: Estudo empirico sobre um resumo minimo de dados de enfermagem (Ph.D. Thesis). Retrieved from http:/hdl.handle.net/10216/7182

Redman, B. K. (2004). Patient selfmanagement of chronic disease: The health care provider's challenge. Sudbury, MA: Jones \& Bartlett Publishers.

Telles-Correia, D., Barbosa, A., Mega, I., Barroso, E., \& Monteiro, E. (2007). Adesão nos doentes transplantados. Acta Médica Portuguesa, 20(1), 73-85. Retrieved from http://repositorio. chlc.min-saude.pt/bitstream/10400.17/622/1/AMP\%20 2007\%2073.pdf

Telles-Correia, D., Barbosa, A., Mega, I., Barroso, E., \& Monteiro, E. (2008). Coping nos doentes transplantados. Acta Médica Portuguesa, 21(2), 141-148. Retrieved from http:// repositorio.chlc.min-saude.pt/bitstream/10400.17/625/1/ AMP\%202008\%20141.pdf 

